\title{
ERGOTERAPIJOS STUDENTŲ KARJEROS GALIMYBIŲ VERTINIMAS COVID-19 PANDEMIJOS SĄLYGOMIS
}

\author{
Morta Girčytė, Milda Gintilienė, Aistė Pranskaitytė-Bielevičienė \\ Kauno kolegijos Medicinos fakulteto Reabilitacijos katedra
}

Raktažodžiai: ergoterapija, studentai, karjera, COVID-19 pandemija.

\begin{abstract}
Santrauka
Tyrimo tikslas - įvertinti ergoterapijos studentų karjeros galimybes COVID-19 pandemijos sąlygomis. Tyrime dalyvavo 78 ergoterapijos studijų programos studentai, kurių amžiaus vidurkis $21,12 \pm 3,29$ metai. Beveik du trečdaliai (62,8 proc.) tyrimo dalyvių, baigę ergoterapijos studijas, ketina dirbti ergoterapeutais. Didžioji dalis (60,3 proc.) studentų ergoterapeutais tikisi įsidarbinti Lietuvoje. Didesnis atlyginimas yra emigraciją skatinantis veiksnys. Daugiau kaip pusè respondentų nurodo, kad pandemijos laikotarpiu yra labiau patenkinti, nei nepatenkinti ergoterapijos studijomis ir nusiteikę tęsti reabilitacijos mokslų studijas. Studentai, vertindami studiju procesą, labiausiai patenkinti dèstomų nuotolinių paskaitų ir praktinių darbų turiniu ir iš dėstytojų sulaukiamu grižztamuoju ryšiu. Didžioji dauguma sutinka, kad aukštosios mokyklos organizuoja projektus ir konferencijas studentu žinių gilinimui, suteikia studentams patogias prieigas prie mokslinès literatūros duomenų bazių ir aukštosios mokyklos bibliotekos. Pasiūlymus pateikę studentai labiausiai pabrèžia kontaktinių užsièmimų, dėstytojų aktyvumo, studentų akademinio sąžiningumo užtikrinimo priemonių poreikị ir studijų kainos koregavimo klausimą.
\end{abstract}

\section{Ivadas}

Lietuvos ergoterapijos studentų požiūrio i j jų karjeros galimybes tyrimas (2008) parodè, kad 75,3 proc. studentų tikisi ịsidarbinti pagal specialybę Lietuvoje. Kaip šį atsakymą argumentuojančią aplinkybę jie nurodè didesni atlyginimą ir karjeros galimybes. I užsienio šalis išvykti darbo tikslais tikejjosi 29,4 proc. respondentų. Pagrindinès išvykimo priežastys - geresnès darbo sąlygos ir labiau motyvuojantis darbo užmokestis. Tyrimo rezultatai parodè, kad trys ketvirtadaliai tyrime dalyvavusių studentų teigiamai atsiliepé apie ergoterapijos studijų kokybę Lietuvoje [9].
COVID-19, kurị sukelia naujas sunkus ūminio kvėpavimo sindromo koronavirusas (SARS-CoV-2), yra tebesitęsianti pandemija, kuri suteikè įtampos ir kai kuriose vietose užvaldè sveikatos priežiūros sistemas [10]. Dabartinè COVID-19 pandemija turi visuotinị poveikị, įskaitant žalą sveikatai, ekonomikai ir švietimui visame pasaulyje [8]. Daugelis žmonių buvo priversti taikyti naujus nuotolinio darbo būdus ir permąstyti savo darbo galimybes, kad prisitaikytų prie COVID-19 pandemijos realijų [3]. Mokslininkų teigimu, klausimai, susiję su pandemijos poveikiu karjerai, tebèra retoriniai [7]. COVID-19 pandemijos metu tarp studentų pastebima psichologinè kančia. Grupè tyrèjų (2021) nustatè, kad didejjantis visaverčio socialinio gyvenimo stygius, ypač izoliacija ir vienatvè, gali būti dalinè psichologinès sveikatos trikdžių priežastis [6]. Šias išvadas patvirtina ir kiti mokslininkai. Jie teigia, kad aukštųjų mokyklų uždarymas ir socialinis atsiribojimas neigiamai veikia kai kurių studentų socialinę integraciją, o tai gali tapti papildomais stresą keliančiais veiksniais [4]. Nuo koronaviruso (COVID-19) pandemijos pradžios yra visiškai aišku, kad būtina ištirti su virusu susijusią patologiją ir jos padarinius sveikatai. Kur kas mažiau aišku, kaip COVID-19 pandemija paveiks būsimujų biomedicinos srities specialistų švietimą [5]. Švietimo sistemos turi neatsilikti nuo spartaus naujų technologijų atsiradimo, todèl mišrus ir nuotolinis mokymasis šiuo metu tampa aukštajo mokslo būtinybe [2]. Lyginant tradicinio ir nuotolinio mokymosi efektyvumą, dauguma studentų nurodo, kad akis ị akị kontaktas su dèstytoju yra svarbus mokymosi veiksnys, kurio trūksta nuotolinio mokymosi metu [1].

Tyrimo tikslas - iqvertinti ergoterapijos studentų karjeros galimybes COVID-19 pandemijos sąlygomis.

\section{Tyrimo medžiaga ir metodai}

Tyrimas vyko 2021 metų sausio - kovo mėnesi. Atsižvelgiant į tyrimo tikslą, buvo taikyta tikslinè imties atranka. Tyrimui pasirinkti Lietuvoje studijuojantys ergoterapijos studentai. Tyrimo imtis buvo sudaryta remiantis 5 proc. paklaidos tikimybe ir 95 proc. pasikliovimo lygiu. Tyrime 
dalyvavo 78 ergoterapijos studentai. Apklausoje dalyvavusiu respondentų amžiaus vidurkis $21,12 \pm 3,29$ metai. Beveik 94 proc. $(\mathrm{n}=73)$ tyrimo dalyvių buvo moterys ir daugiau, kaip 6 proc. $(\mathrm{n}=5)$ vyrai ( 1 pav. $)$.

Tyrimo duomenims surinkti buvo naudojama autorès sukurta anoniminė anketa. Apklausą sudarè 15 uždarų ir pusiau atvirų klausimų. Klausimynas suskirstytas į 4 dalis:

1 - ivvadinè dalis. Respondentai supažindinami su tyrimo tikslu, informuojami apie anketos anonimiškumą. Suteikiama trumpa anketos pildymo instrukcija;

2 - karjeros galimybių vertinimas ( 1 - 6 klausimai). Tai plačiausia anketos dalis, atskleidžianti temos turinį. Šią dalị sudaro klausimai apie ergoterapijos studijų pasirinkimo priežastis, ịsidarbinimo galimybių lūkesčius, emigracijos galimybes ir ịtakos turinčius veiksnius. Šią dalį galima suskirstyti i smulkesnes grupes: pirmosios grupès klausimu (1 klausimas) prašoma nurodyti ergoterapijos studiju pasirinkimo priežastis, antrosios grupès klausimais (2-3) siekiama išsiaiškinti respondentų ketinimą dirbti pagal igytą ergoterapeuto specialybę ir ergoterapeuto, kaip specialisto karjeros sieki motyvuojančias priežastis. Trečiosios grupès klausimais (4-6) norima išsiaiškinti, ar studentai tikisi dirbti Lietuvoje, ar planuoja emigruoti ir kokie yra emigraciją skatinantys veiksniai;

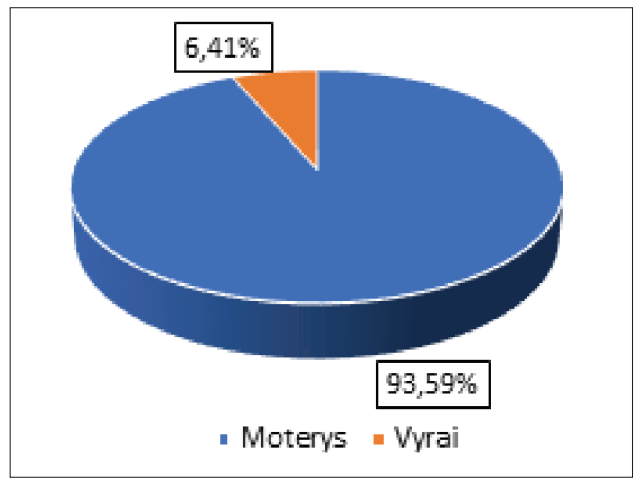

1 pav. Lyčių skirstinys

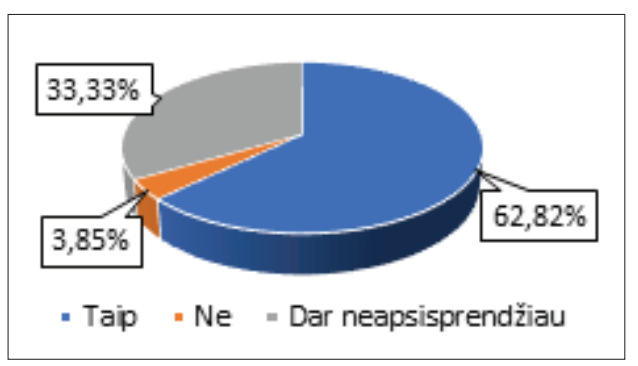

2 pav. Studentų ketinimai baigus studijas dirbti ergoterapeutu
3 - studijų vertinimas. Klausimai (7-10), atskleidžiantys studentų nuomonę apie studijų privalumus ir trūkumus COVID - 19 pandemijos sąlygomis, ką reikètų keisti studiju programoje ir planus tęsti ar pradèti naujas studijas;

4 - demografinè dalis- klausimai (11-15), nurodantys respondento lytį, amžių, aukštają mokyklą, miestą, kuriame studijuoja ir studijų kursą.

Duomenų analizė vykdyta Microsoft Office Excel (2016) ir PSPP 1.4 programomis.

\section{Tyrimo rezultatai ir jų aptarimas}

Tyrimo metu buvo siekiama išsiaiškinti ergoterapijos studentų požiūrị i karjeros galimybes. Remiantis šiuo uždaviniu, respondentų buvo klausiama, ar jie baigę studijas ketina dirbti pagal igytą specialybę ir kas juos motyvuotų siekti ergoterapeuto karjeros. Beveik du trečdaliai $(62,8$ proc., $\mathrm{n}=49$ ) tyrimo dalyvių, baigę ergoterapijos studijas, ketina dirbti ergoterapeutais, trečdalis $(33,3$ proc., $n=26)$ respondentų teigia, kad dar nèra apsisprendę, ar baigę studijas dirbs ergoterapeutais. Mažiausiai ( 3,8 proc., $n=3)$ respondentų pažymėjo, kad baigę studijas neketina dirbti ergoterapeutais (2 pav.).

1 lentelè. Būsimujjų ergoterapeutų karjeros siekị motyvuojantys veiksniai.

\begin{tabular}{|l|c|c|}
\hline \multicolumn{3}{|c|}{ Kas, Jūsų nuomone, Jus motyvuotų siekti ergotera- } \\
peuto(-ès) karjeros?
\end{tabular}

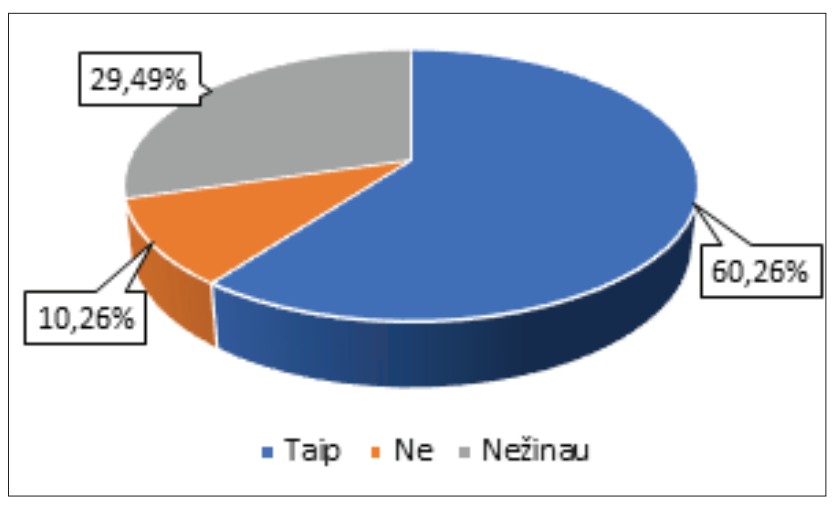

3 pav. Studentų prognozės Lietuvoje įsidarbinti pagal ergoterapeuto specialybę 
Siekiant išsiaiškinti, kas studentus motyvuotu siekti ergoterapeuto karjeros, apklausoje buvo galima pasirinkti kelis atsakymo variantus. Labiausiai išryškejjo tokie motyvuojantys veiksniai, kaip noras gilinti jau sukauptas žinias ir atlygis už darbą. Respondentų nuomone, mažiausiai karjeros siekị motyvuojantis veiksnys - kolegų ịvertinimas ir igytas pasitikejjimas (1 lentelè). Studentų paminètos kitos priežastys buvo galimybẻ prisidèti prie pacientų (klientų) savarankiškumo didinimo jų kasdienybèje, galimybė greitai po studijų susirasti darbą ir didesni ergoterapeutų darbo vietų skaičių.

Apibendrinant šiuos rezultatus, galime teigti, kad beveik du trečdaliai tyrime dalyvavusių studentų yra nusiteikę siekti ergoterapeuto karjeros, o kaip karjeros siekị motyvuojančius veiksnius jie labiausiai išskiria norą gilinti jau sukauptas žinias ir atlygị už darbą.

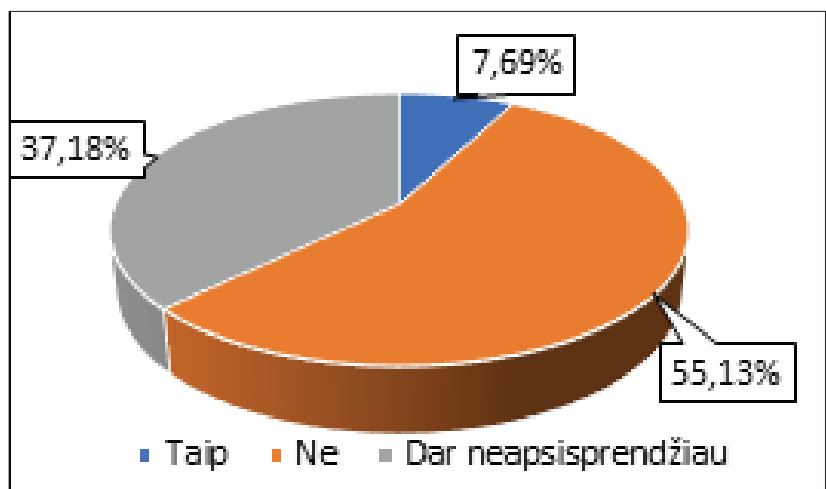

4 pav. Respondentų apsisprendimas baigus studijas išvykti dirbti ergoterapeutu ị užsienio šalis

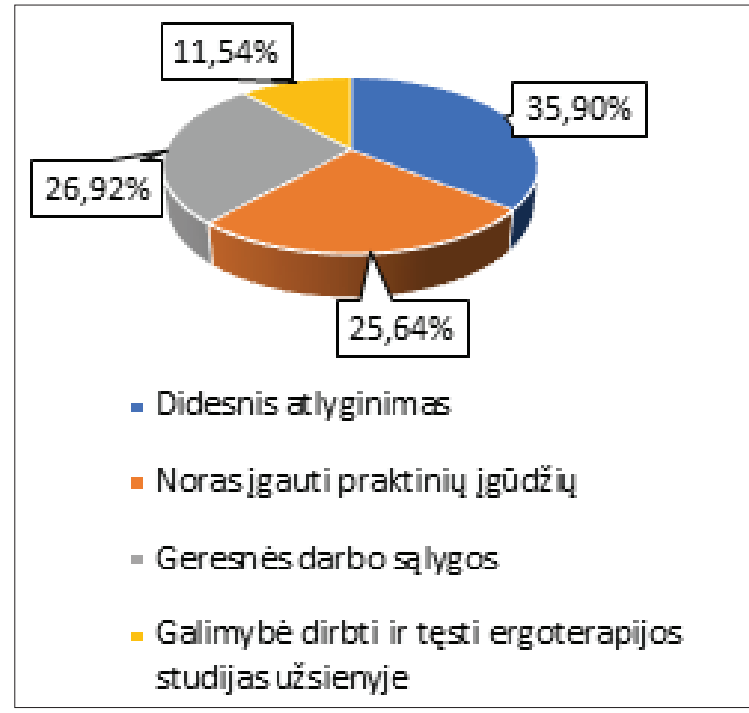

5 pav. Respondentus skatinantys dirbti užsienio šalyse veiksniai
Ar ergoterapijos studentai ketina likti dirbti Lietuvoje, ar svarsto galimybę išvykti dirbti ị užsienio šalis ir kokie kriterijai turi ịtakos jų apsisprendimui, 60,3 proc. $(n=47)$ tyrimo dalyvių atsake teigiamai (3 pav.).

Nagrinejjant studentų atsakymus apie išvykimą i užsienį, aiškiai daugiau kaip pusè $(55,1$ proc., $n=43)$ tiriamujų, baigę studijas, neplanuoja išvykti ị užsienio šalis dirbti ergoterapeutais. Apie galimybę emigruoti galvoja tik 8 proc. $(n=6)$ tyrime dalyvavusių studentų. Likusioji dalis (37,2 proc., $\mathrm{n}=29$ ) teigia, kad dar nèra apsisprendę (4 pav.).

Labiausiai emigraciją motyvuojantis veiksnys - didesnis atlyginimas, ji pasirinko daugiau nei trečdalis ( 35,9 proc., $\mathrm{n}=28$ ) tyrimo dalyvių. Iš kitų, labiausiai emigraciją skatinančių veiksnių, respondentai išskyrè norą iggauti praktinių igūdžių ir užsienio šalyse siūlomas geresnes darbo sąlygas. Likusioji dalis (11,54 proc., n=9) tiriamujų pažymėjo, kad juos skatina galimybe dirbti ir tęsti ergoterapijos studijas užsienyje (5 pav.).

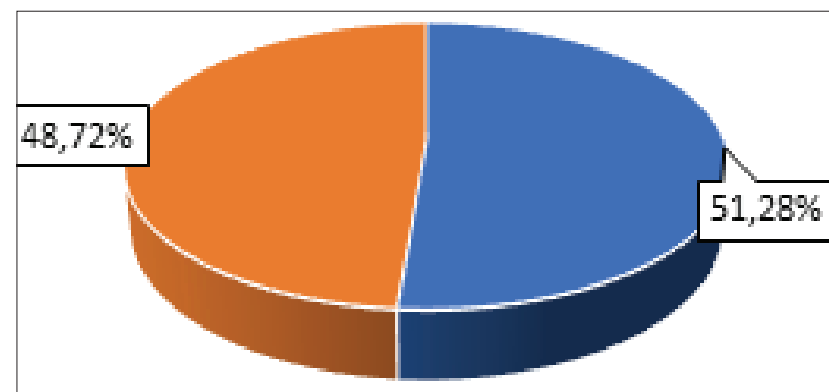

- Labiau patenkint $æ(-a)$, nei nepatenkintas(-a)

6 pav. Respondentų pasitenkinimas nuotolinėmis ergoterapijos studijomis Covid-19 pandemijos sąlygomis

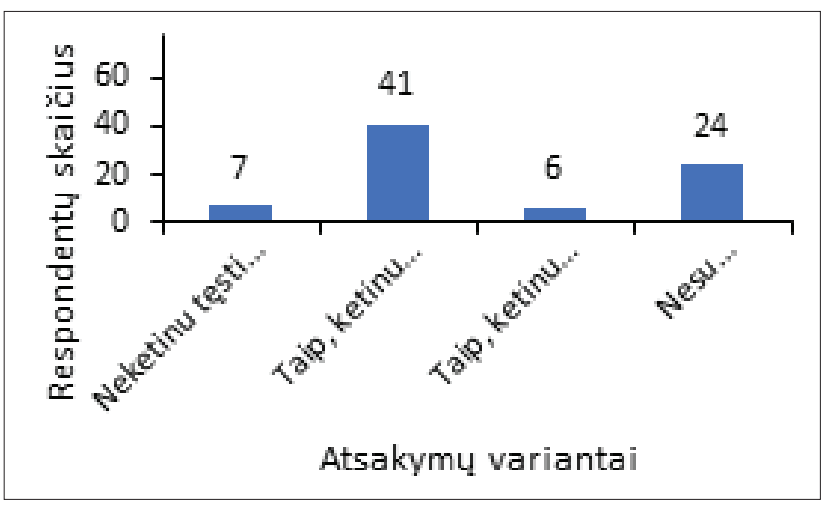

7 pav. Respondentų atsakymai ị klausimą „Kaip manote, ar tęsite studijas toliau?“" 
Apibendrinant galima teigti, kad dauguma studentų tikisi dirbti ergoterapeutais Lietuvoje ir neplanuoja išvykti ị užsienio šalis. Didesnis atlyginimas yra emigraciją skatinantis veiksnys.

Tyrimo metu buvo siekiama išsiaiškinti ergoterapijos studentų nuomonę apie studijų procesą COVID-19 pandemijos metu. Pirmieji 6 teiginiai susiję su nuotolinių paskaitų, praktinių užsiemimų, nuotolinių atsiskaitymų kokybe COVID-19 pandemijos metu ir studentų dalyvavimu priimant tvarkaraščių ir studijų proceso organizavimo pataisas. I t pirmajị teiginį „Dèstytojai vaizdžiai ir

2 lentelè. Studentų nuomonė apie studijų procesą COVID-19 pandemijos metu (1).

\begin{tabular}{|c|c|c|c|c|c|}
\hline $\begin{array}{l}\text { Teiginiai, susiję su studijų procesu } \\
\text { COVID-19 pandemijos metu }\end{array}$ & 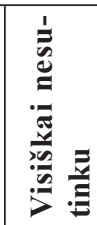 & 疍 & 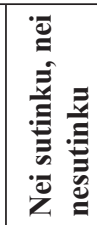 & 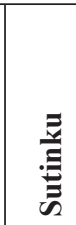 & 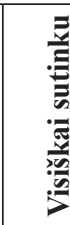 \\
\hline & \multicolumn{5}{|c|}{ skaičiai, procentais } \\
\hline $\begin{array}{l}\text { 1. Dėstytojai vaizdžiai ir produktyviai rengia } \\
\text { praktinius užsièmimus nuotoliniu būdu }\end{array}$ & 5,1 & 8,9 & 32,1 & 44,9 & 9 \\
\hline $\begin{array}{l}\text { 2. Mane tenkina daugumos dèstytojų pasi- } \\
\text { rengimas paskaitoms, jų pateikiama moko- } \\
\text { moji medžiaga }\end{array}$ & 5,1 & 11,5 & 25,6 & 42,3 & 15,4 \\
\hline $\begin{array}{l}\text { 3. Visada gaunu atsakymus ị visus paskaitos } \\
\text { metu iškilusius klausimus }\end{array}$ & 3,8 & 7,7 & 20,5 & 46,2 & 21,8 \\
\hline $\begin{array}{l}\text { 4. Nuotolinių atsiskaitymų forma ir trukmè } \\
\text { puikiai suplanuoti }\end{array}$ & 7,7 & 19,2 & 37,2 & 28,2 & 7,7 \\
\hline $\begin{array}{l}\text { 5. Tvarkaraščių koregavimas atliekamas } \\
\text { suderinus su studentais }\end{array}$ & 9 & 15,4 & 32,1 & 26,9 & 16,7 \\
\hline $\begin{array}{l}\text { 6. Visada svarbi studentų nuomonè, kuriant } \\
\text { studiju proceso organizavimo pataisas }\end{array}$ & 5,1 & 14,1 & 39,7 & 28,2 & 12,8 \\
\hline
\end{tabular}

3 lentelè. Studentų nuomonè apie studijų procesą COVID-19 pandemijos metu (2).

\begin{tabular}{|c|c|c|c|c|c|}
\hline $\begin{array}{l}\text { Teiginiai, susiję su studijų procesu CO- } \\
\text { VID-19 pandemijos metu }\end{array}$ & 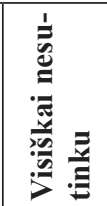 & 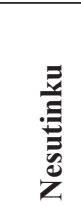 & 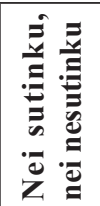 & 竞 & 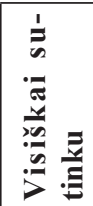 \\
\hline & \multicolumn{5}{|c|}{ skaičiai, procentais } \\
\hline $\begin{array}{l}\text { 7. Aukštoji mokykla padeda ieškant prak- } \\
\text { tikos vietų }\end{array}$ & 6,4 & 10,3 & 42,3 & 25,6 & 15,4 \\
\hline $\begin{array}{l}\text { 8. Aukštojoje mokykloje vykdomi projektai, } \\
\text { tyrimai, organizuojamos konferencijos, skir- } \\
\text { tos Jūsų žinių ir gebejjimų gilinimui }\end{array}$ & 2,6 & 2,6 & 28,2 & 55,1 & 11,5 \\
\hline $\begin{array}{l}\text { 9. Studentai skatinami savanoriauti, siekiant } \\
\text { gilinti praktnius ịgūžius }\end{array}$ & 6,4 & 12,8 & 32,1 & 41 & 7,7 \\
\hline $\begin{array}{l}\text { 10. Aukštoji mokykla suteikia prieigas prie } \\
\text { mokslinès literatūros duomenų bazių }\end{array}$ & 3,8 & 1,3 & 15,4 & 42,3 & 37,2 \\
\hline $\begin{array}{l}\text { 11. Studentams lengvai prieinama aukštosios } \\
\text { mokyklos biblioteka }\end{array}$ & 3,8 & 1,3 & 9 & 48,7 & 37,2 \\
\hline $\begin{array}{l}\text { 12. Aukštoji mokykla suteikia reikalingas } \\
\text { priemones mokslinių tyrimų vykdymui }\end{array}$ & 6,4 & 9 & 42,3 & 35,9 & 6,4 \\
\hline
\end{tabular}

produktyviai rengia praktinius užsièmimus nuotoliniu būdu“ dažniausiai $(53,9$ proc.) buvo atsakyta teigiamai: sutinku - 44,9 proc., visiškai sutinku - 9 proc. Kitas teiginys „Mane tenkina daugumos dèstytojų pasirengimas paskaitoms, jų pateikiama mokomoji medžiaga" studentų įvertintas taip pat teigiamai. Su šiuo teiginiu sutiko daugiau kaip puse ( 57,7 proc.) tyrimo dalyvių: sutinku 42,3 proc., visiškai sutinku - 15,4 proc. Su trečiuoju teiginiu „Visada gaunu atsakymus ị visus paskaitos metu iškilusius klausimus" sutiko daugiau nei du trečdaliai (68 proc.) tyrime dalyvavusių studentų: sutinku - 46,2 proc., visiškai sutinku $-21,8$ proc. Studentai labiau teigiamai, nei neigiamai ịvertino teigini „Nuotolinių atsiskaitymų forma ir trukmè puikiai suplanuoti“. Su šiuo teiginiu sutiko šiek tiek daugiau, nei trečdalis (35,9 proc. ) studentų: sutinku $-28,2$ proc., visiškai sutinku $-7,7$ proc. I penktaji teigini „Tvarkaraščių koregavimas atliekamas suderinus su studentais" ergoterapijos studentai daugiausia (43,6 proc.) atsakè teigiamai: sutinku 26,9 proc., visiškai sutinku - 16,7 proc. Šeštasis teiginys ,Visada svarbi studentu nuomoné, kuriant studijų proceso organizavimo pataisas" studentų nuomone, taip pat yra teisingas. Su juo sutiko 41 proc. tiriamujų: sutinku $-28,2$ proc., visiškai sutinku - 12,8 proc. (2 lentelè).

Kiti 6 teiginiai apibūdina Lietuvos aukštujų mokyklų teikiamą pagalbą, siekiant gilinti studentų žinias ir suteikti mokymosi procesui reikalingų išteklių. Teiginys „Aukštoji mokykla padeda ieškant praktikos vietų“ studentų įvertintas labiau teigiamai, nei neigiamai. $\mathrm{Su}$ šiuo teiginiu sutiko 41 proc. apklaustųjų: sutinku - 25,6 proc., visiškai sutinku 15,4 proc. Tiriamujų nuomone, teiginys „Aukštojoje mokykloje vykdomi projektai, tyrimai, organizuojamos konferencijos, skirtos Jūsų žinių ir gebejjimų gilinimui“", yra teisingas. Du trečdaliai (66,6 proc.) i š ši teigini atsakè teigiamai: sutinku - 55,1 proc., visiškai sutinku - 
11,5 proc. I teigini „Studentai skatinami savanoriauti, siekiant gilinti praktinius igūdžius", beveik pusè (48,7 proc.) respondentu atsakè teigiamai: sutinku -41 proc., visiškai sutinku - 7,7 proc.). Labiausiai respondentai abejojo dèl paskutinio teiginio „Aukštoji mokykla suteikia reikalingas priemones mokslinių tyrimų vykdymui“". Rezultatai parodè, kad dauguma (42,3 proc.) nei sutinka, nei nesutinka su šiuo teiginiu: sutinku $-35,9$ proc., visiškai sutinku $-6,4$ proc. (3 lentelè).

Labiausiai studentai patenkinti nuotolinių paskaitų, praktinių darbų turiniu ir grịžtamuoju ryšiu iš dėstytojų, aukštosios mokyklos organizuojamais projektais ir konferencijomis žinių gilinimui, lengvai prieinamomis prieigomis prie mokslinès literatūros duomenų bazių ir aukštosios mokyklos bibliotekos.

Studentų atsakymai apie pasitenkinimą nuotolinėmis studijomis Covid-19 pandemijos sąlygomis pasiskirsté apylygiai: 51,28 proc. $(\mathrm{n}=40)$ tyrimo dalyvių teigè, kad yra labiau patenkinti ergoterapijos studijomis COVID-19 pandemijos metu. Kiti $(48,72$ proc., $n=38)$ nurode, kad yra labiau nepatenkinti ergoterapijos studijomis šiuo metu (6 pav.).

Apie galimybę po ergoterapijos studijų tęsti studijas reabilitacijos ar kitose srityse, dauguma ergoterapijos studentu $(52,6$ proc., $\mathrm{n}=41)$ nurodè, kad planuoja tęsti reabilitacijos mokslų krypties studijas, mažiau nei trečdalis $(30,8$ proc., $\mathrm{n}=24)$ dar nèra apsisprendę dèl studijų tęsimo, 9 proc. $(\mathrm{n}=7)$ studentų net neplanuoja ir likusioji dalis $(7,7$ proc., $n=6)$ po baigimo ketina pradeti naujas studijas (7 pav.).

Dauguma tyrime dalyvavusių studentų yra nusiteikę gilinti reabilitacijos mokslų krypties žinias.

It tyrimo klausimą apie pasiūlymus, kaip patobulinti studijų proceso eigą pandemijos metu, du trečdaliai (66,7 proc., $\mathrm{n}=52$ ) tyrimo dalyvių siūlè nieko nekeisti. Likęs trečdalis $(33,3$ proc., $n=26)$ apklaustujų net ịvardijo pasiūlymus: teorinius užsièmimus rengti nuotoliniu būdu, o praktinius kontaktiniu; atsiskaitymų organizavimui imtis priemonių, kurios užtikrintų studentų akademinị sąžiningumą ir atskleistų jų realias žinias; mažiau kontrolès ir daugiau pasitikẻjimo studentais kaip suaugusiais žmonėmis; siekti dėstytojų aktyvumo, atsakingumo ir pagalbos teikimo studentams, nes kai kurie naudojasi situacija ir duoda mažiau informacijos, teigdami, kad studentai nieko neveikia pandemijos metu, todèl gali dirbti savarankiškai.

\section{Išvados}

1. Ergoterapijos studentai, nepaisant COVID-19 pandemijos, nusiteikę siekti ergoterapeutų karjeros. Karjerą motyvuojantys veiksniai - noras gilinti sukauptas žinias ir atlygis už darbą.
2. Dauguma studentų tikisi dirbti ergoterapeutais Lietuvoje ir neplanuoja išvykti ị užsienio šalis. Didesnis atlyginimas ịvardijamas kaip veiksnys, skatinantis darbo pasirinkimą užsienio šalyse.

3. Studentai yra labiau patenkinti, nei nepatenkinti ergoterapijos studijomis pandemijos laikotarpiu ir nusiteikę toliau gilinti reabilitacijos mokslų žinias. Studijų kokybès gerinimui studentai dažniausiai pabrèžia kontaktinių užsièmimų, dèstytojų aktyvumo, priemonių studentų akademinio sąžiningumo užtikrinimui poreikị ir studijų kainos koregavimo klausimą.

\section{Literatūra}

1. Adnan M, Anwar K. Online learning amid the COVID-19 pandemic: Students' perspectives. Journal of Pedagogical Sociology and Psychology 2020;2(1):45-51.

https://doi.org/10.33902/JPSP.2020261309

2. Ali W. Online and remote learning in higher education institutes: A necessity in light of COVID-19 pandemic. Higher Education Studies 2020;10(3), 16-25.

https://doi.org/10.5539/hes.v10n3p16

3. Dwivedi YK, et al. Impact of COVID-19 pandemic on information management research and practice: Transforming education, work and life. International Journal of Information Management 2020;55: 102211.

https://doi.org/10.1016/j.ijinfomgt.2020.102211

4. Elmer T, Mepham K, Stadtfeld C. Students under lockdown: Comparisons of students' social networks and mental health before and during the COVID-19 crisis in Switzerland. Plos One 2020;15(7): e0236337.

https://doi.org/10.1371/journal.pone.0236337

5. Ferrel MN, Ryan JJ. The impact of COVID-19 on medical education. Cureus 2020;12(3).

https://doi.org/10.7759/cureus.7492

6. Hamza CA, Ewing L, Heath NL, Goldstein AL. When social isolation is nothing new: A longitudinal study on psychological distress during COVID-19 among university students with and without preexisting mental health concerns. Canadian Psychology/Psychologie Canadienne 2021;62(1):20.

https://doi.org/10.1037/cap0000255

7. Hite LM, Mcdonald KS. Careers after COVID-19: challenges and changes. Human Resource Development International 2020; 23.4: 427-437.

https://doi.org/10.1080/13678868.2020.1779576

8. Levine RL, Rathmell WK. COVID-19 impact on early career investigators: a call for action. Nature Reviews Cancer 2020;20(7):357-358.

https://doi.org/10.1038/s41568-020-0279-5

9. Liškauskienė L. Ergoterapijos studentų karjeros galimybių vertinimas. 2008. https://publications.lsmuni.lt/object/elaba:2005489/index.html 
10. Singer BD. COVID-19 and the next influenza season. Science Advances 2020;6(31).

https://doi.org/10.1126/sciadv.abd0086

\section{ASSESSMENT OF CAREER OPPORTUNITIES OF OCCUPATIONAL THERAPY STUDENTS IN THE CONDITIONS OF COVID-19 PANDEMIC}

\section{Girčytė, M. Gintilienė, A. Pranskaitytė-Bielevičienė}

Keywords: occupational therapy, students, career, COVID-19 pandemic.

Summary

The aim - to evaluate career opportunities of the occupational therapy students in the conditions of COVID-19 pandemic.

The study involved 78 students from the occupational therapy study program with an average age of $21.12 \pm 3.29$ years. Approximately, $94 \%(n=73)$ of participants are females. Almost two thirds of the participants are intend to work as occupational therapists after completing their occupational therapy studies. The majority $(60.3 \%)$ of participants is expecting to be employed as occupational therapists in Lithuania. In order to find out what would encourage occupational therapy students to go to work abroad, higher wages were found to be a driver of emigration. More than half (51.3 per cent) of respondents report being satisfied with occupational therapy studies during this pandemic period, and are willing to continue their studies in the field of rehabilitation sciences. Students are most satisfied with the content of distance lectures and practical works taught and receive feedback from teachers when assessing the study process. The vast majority also agree that higher education institutions organise projects and conferences to improve students' knowledge and provide students with easily accessible access to scientific literature databases and higher education libraries. The majority $(66.7 \%)$ of students suggest that nothing should be changed in the course of the study process, and the students who submitted proposals most emphasize the need for contact classes, teacher activity, measures to ensure students ' academic integrity and the question of adjusting the cost of studies.

Correspondence to: milda.gintiliene@go.kauko.lt

Gauta 2021-11-14 